\title{
Indoor carbon dioxide concentrations in Croatian elementary school classrooms during the heating season
}

\author{
Dario Brdarić1,2, Krunoslav Capak ${ }^{3}$, Vlatka Gvozdić4 ${ }^{4}$ Andrea Barišinn ${ }^{3}$, Jagoda Doko Jelinić5 \\ Andrey Egorov ${ }^{6}$, Matej Šapina ${ }^{2,7,8}$, Sanja Kalambura9 ${ }^{9}$, and Karolina Kramarićc ${ }^{2,7,8}$ \\ ${ }^{1}$ Institute of Public Health for the Osijek-Baranya County, Osijek, Croatia \\ ${ }^{2}$ Faculty of Dental Medicine and Health, Josip Juraj Strossmayer University of Osijek, Osijek, Croatia \\ ${ }^{3}$ Croatian Institute of Public Health, Zagreb, Croatia \\ ${ }^{4}$ Department of Chemistry, Josip Juraj Strossmayer University of Osijek, Osijek, Croatia \\ ${ }^{5}$ School of Public Health “Andrija Štampar”, School of Medicine, University of Zagreb, Zagreb, Croatia \\ ${ }^{6}$ European Centre for Environment and Health, World Health Organization, Bonn, Germany \\ ${ }^{7}$ Clinical Hospital Osijek, Osijek, Croatia \\ ${ }^{8}$ School of Medicine, Josip Juraj Strossmayer University of Osijek, Osijek, Croatia \\ ${ }^{9}$ University of Applied Sciences Velika Gorica, Velika Gorica, Croatia
}

[Received in September 2019; Similarity Check in October 2019; Accepted in December 2019]

\begin{abstract}
Aware that exposure to stuffy indoor air with high levels of carbon dioxide $\left(\mathrm{CO}_{2}\right)$ is associated with higher absenteeism and reduced academic performance in school pupils, the World Health Organization (WHO) Regional Office for Europe initiated indoor air quality surveys in schools, including $\mathrm{CO}_{2}$ monitoring, to assess ventilation and exposure to stuffy air. Here we report the findings of the first such survey in Croatia. It was conducted in 60 classrooms of 20 urban and rural elementary schools throughout the country during the heating season. Measurements of $\mathrm{CO}_{2}$ levels showed that all 60 classrooms exceeded the international guidelines of $1938 \mathrm{mg} / \mathrm{m}^{3}$. Mean $\mathrm{CO}_{2}$ concentrations ranged from 2771 to $7763 \mathrm{mg} / \mathrm{m}^{3}$. The highest concentration measured in urban schools was $7763 \mathrm{mg} / \mathrm{m}^{3}$ and in rural schools $4771 \mathrm{mg} / \mathrm{m}^{3}$. Average CO, levels were higher in continental schools $\left(3683 \mathrm{mg} / \mathrm{m}^{3}\right)$ than the coastal ones $\left(3134 \mathrm{mg} / \mathrm{m}^{3}\right)$, but all demonstrate poor ventilation during the heating season all over Croatia.
\end{abstract}

KEY WORDS: $\mathrm{CO}_{2}$; indoor air quality; ventilation

Children belong to the most vulnerable social groups to a variety of air pollutants (1). In contrast to adults, their organs are still maturing, they inhale more air per body weight, and are less resistant to environmental factors that may impair their health and cognitive performance in the long run (2-4).

After homes, schools are the second most important place of child exposure to indoor pollutants, and the level of exposure is directly associated with classroom ventilation, which, in turn, is closely associated with health (5-7). According to the World Health Organization (WHO) Regional Office for Europe report (8), $\mathrm{CO}_{2}$ concentrations in classrooms serve as a proxy for ventilation rates and recommendations for maximum values vary from 1938 to $2907 \mathrm{mg} / \mathrm{m}^{3}$ (1000-1500 ppm). Health effects of poor ventilation ("stuffy air") in classrooms range from headaches and respiratory infections, which result in absenteeism, to lower cognitive performance and learning

Corresponding author: Vlatka Gvozdić, Josip Juraj Strossmayer University of Osijek, Department of Chemistry, Cara Hadrijana 8/A, 31000 Osijek, Croatia, E-mail: vlatka.gvozdic@kemija.unios.hr
(9-12). Satish et al. (13) found that cognitive performance was slightly worse at $\mathrm{CO}_{2}$ concentrations of $1938 \mathrm{mg} / \mathrm{m}^{3}$ and substantially worse at $4845 \mathrm{mg} / \mathrm{m}^{3}$. According to Janssen et al. (14), the quality of indoor air environment in schools can be affected by insufficient ventilation, especially in winter, presence of indoor emission sources, such as furniture and building materials, and crowded classrooms.

In educational facilities, indoor $\mathrm{CO}_{2}$ concentration serves as an indicator of indor air quality (15), and several studies have assessed $\mathrm{CO}_{2}$ concentrations in indoor school environment and children's exposure to indoor pollution (16-20).

In line with the commitment to prevent diseases in children by improving outdoor and indoor air quality set out in the Parma Declaration (21), the WHO European Centre for Environment and Health (ECEH) and its partner institutions developed standardised methodology for comprehensive assessment of exposures in the school environment (22).

In 2012, WHO ECEH and the Public Health Institute of the Osijek-Baranja County set up a pilot project in the 
schools of Osijek (Eastern Croatia) to implement standard WHO data collection tools to Croatian settings (23), which then gave way to a comprehensive survey at the national level (24). Here we report the results of this national survey.

\section{MATERIALS AND METHODS}

The survey was conducted in 20 randomly selected schools in 10 counties across Croatia from February to May 2014 (Figure 1) and involved monitoring of 60 classrooms (3 classrooms per school) during one school week, Monday morning to Friday evening, for $24 \mathrm{~h}$ a day, to obtain daily fluctuations $\mathrm{CO}_{2}$ in real-life settings. The schools were selected to cover all geographic locations and socioeconomic environments (rural, urban, coastal and continental). Nine of twenty selected schools were located in rural areas; six schools were located in the coastal region. Only one school had a mechanical ventilation system, while others were ventilated by opening doors and windows.

Carbon dioxide levels, temperature, and relative humidity were measured with compact Kistock KTH-CO (Kimo, Rennes, France) monitors with data loggers and memory sufficient to retain 20,000 recordings. Carbon dioxide was recorded at one-minute intervals with the upper limit of quantitation of $9689 \mathrm{mg} / \mathrm{m}^{3}$ and accuracy of \pm (96.9 $\mathrm{mg} / \mathrm{m}^{3}+3 \%$ of the measured value). Relative humidity and temperature were recorded continuously with the accuracy of $\pm 2 \%$ for relative humidity and $\pm 0.5^{\circ} \mathrm{C}$ for temperature (both at temperatures from $15^{\circ} \mathrm{C}$ to $25^{\circ} \mathrm{C}$ ). The monitors were calibrated for each parameter using a two-point adjustment method, in which a new slope and a new offset are automatically calculated based on high and low calibration values (25).

\section{Statistical analysis}

For statistical analysis we used the Statistica software v. 7.1 (StatSoft Inc., Tulsa, OK, USA). Numerical data are reported descriptively as medians and interquartile ranges. Normality of distribution was tested with the KolmogorovSmirnov test. Between-group differences were assessed with the Mann-Whitney U test. Hierarchical clustering using the complete linkage method with Euclidean distance was applied according to our hypothesis that different schools could be clustered by similar features. P values of less than 0.05 were considered statistically significant.

\section{RESULTS AND DISCUSSION}

\section{School characteristics}

The school sizes ranged from 103 to 767 pupils. Classroom volumes varied from 60 to $334 \mathrm{~m}^{3}$. The average

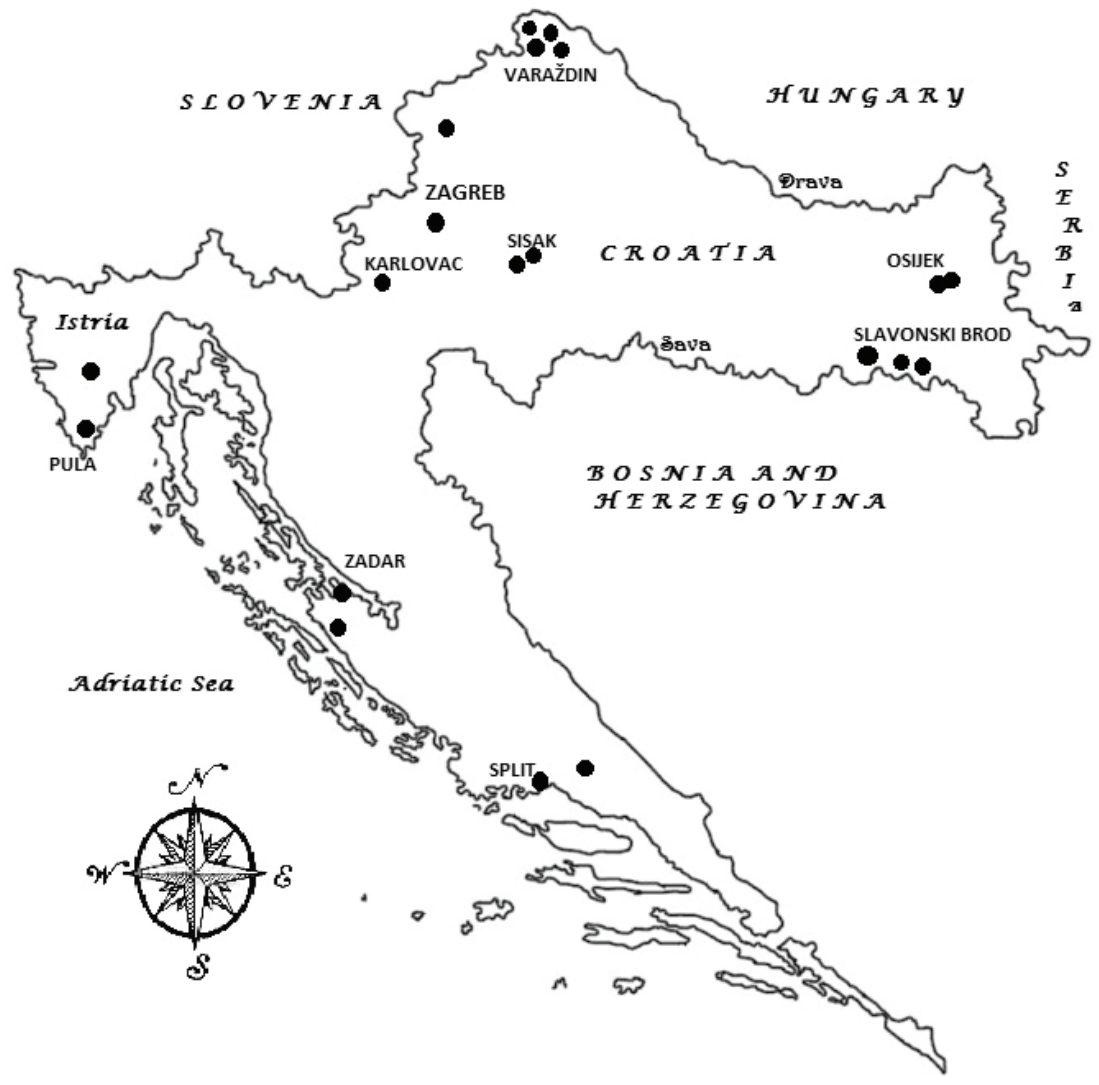

Figure 1 Locations of schools participating in indoor air monitoring 
Table 1 Indoor air parameters and main characteristics of 20 schools (averages from three classrooms)

\begin{tabular}{lllllccccc}
\hline No. & Type & Location & $\begin{array}{c}\text { TFA } \\
\left(\mathbf{m}^{2}\right)\end{array}$ & $\mathbf{N P}$ & $\mathbf{R V}\left(\mathbf{m}^{3}\right)$ & $\begin{array}{c}\mathbf{F A P} \\
\left(\mathbf{m}^{2} / \mathbf{p u p i l}\right)\end{array}$ & $\begin{array}{c}\mathbf{T} \\
\left({ }^{\circ} \mathbf{C}\right)\end{array}$ & $\begin{array}{c}\mathbf{R H} \\
(\mathbf{\%})\end{array}$ & $\begin{array}{c}\mathbf{C O}_{2} \\
\left(\mathbf{m g} / \mathbf{m}^{3}\right)\end{array}$ \\
\hline 1 & Urban & Continental & 4750 & 586 & 162 & 8.10 & 21.3 & 49.2 & 4690 \\
\hline 2 & Rural & Continental & 3500 & 636 & 180 & 5.50 & 22.7 & 37.7 & 3521 \\
\hline 3 & Urban & Continental & 1553 & 705 & 231 & 2.20 & 21.8 & 39.3 & 3180 \\
\hline 4 & Rural & Continental & 1600 & 205 & 144 & 7.80 & 21.8 & 43.6 & 3616 \\
\hline 5 & Urban & Continental & 1400 & 531 & 152 & 2.63 & 21.9 & 31.2 & 3583 \\
\hline 6 & Rural & Continental & 837 & 103 & 123 & 8.12 & 20.8 & 60.2 & 3612 \\
\hline 7 & Urban & Continental & 3000 & 504 & 117 & 5.95 & 22.9 & 54.7 & 3819 \\
\hline 8 & Rural & Continental & 1390 & 217 & 215 & 6.40 & 21.9 & 45.9 & 4224 \\
\hline 9 & Urban & Continental & 3100 & 738 & 210 & 4.20 & 23.2 & 42.3 & 4213 \\
\hline 10 & Urban & Continental & 3000 & 378 & 334 & 7.93 & 20.3 & 54.8 & 5346 \\
\hline 11 & Urban & Continental & 6000 & 767 & 192 & 7.82 & 20.9 & 47.5 & 3841 \\
\hline 12 & Rural & Continental & 1542 & 328 & 308 & 4.70 & 21.4 & 34.6 & 4036 \\
\hline 13 & Urban & Continental & 2338 & 377 & 210 & 6.20 & 22.5 & 49.8 & 3695 \\
\hline 14 & Rural & Continental & 3600 & 186 & 130 & 19.35 & 20.1 & 50.2 & 4209 \\
\hline 15 & Rural & Coastal & 2100 & 273 & 173 & 7.69 & 21.6 & 45.3 & 3302 \\
\hline 16 & Urban & Coastal & 2600 & 570 & 262 & 4.56 & 21.4 & 54.2 & 3515 \\
\hline 17 & Rural & Coastal & 360 & 205 & 162 & 1.75 & 21.6 & 49.7 & 3486 \\
\hline 18 & Rural & Coastal & 1158 & 130 & 134 & 8.90 & 20.7 & 40.8 & 2951 \\
\hline 19 & Rural & Coastal & 2200 & 521 & 60 & 4.22 & 20.6 & 43.4 & 3428 \\
\hline 20 & Urban & Coastal & 3750 & 524 & 70 & 7.15 & 20.8 & 42.1 & 3593 \\
\hline
\end{tabular}

TFA - total floor area; NP - number of pupils; RV - room volume; FAP - floor area per pupil; T - temperature; RH - relative humidity

classroom temperature varied from 20.1 to $23.3{ }^{\circ} \mathrm{C}$, and relative humidity from 31.2 to $60.2 \%$.

\section{$\mathrm{CO}_{2}$ concentrations}

The mean $\mathrm{CO}_{2}$ concentration for all 60 classrooms was $3767 \pm 1393 \mathrm{mg} / \mathrm{m}^{3}$ (median $3339 \mathrm{mg} / \mathrm{m}^{3}$ ), and the measurements ranged from $901 \mathrm{mg} / \mathrm{m}^{3}$ to the upper limit of quantitation of $9689 \mathrm{mg} / \mathrm{m}^{3}$. All the 60 classrooms had mean $\mathrm{CO}_{2}$ levels above the recommendations from WHO report of 1938 to $2907 \mathrm{mg} / \mathrm{m}^{3}$ (8).

Maximum $\mathrm{CO}_{2}$ concentrations coincided with the school day between 8 am and $6 \mathrm{pm}$, as the classes were organised in two shifts in all schools. Classrooms were not ventilated after the school day. Overnight, $\mathrm{CO}_{2}$ dropped to concentrations between $1938 \mathrm{mg} / \mathrm{m}^{3}$ and $3876 \mathrm{mg} / \mathrm{m}^{3}$.

$\operatorname{Rural}\left(\mathrm{N}=27 ; 3381 \mathrm{mg} / \mathrm{m}^{3}\right)$ and urban $\left(\mathrm{N}=33 ; 3629 \mathrm{mg} / \mathrm{m}^{3}\right)$ schools did not significantly differ in mean $\mathrm{CO}_{2}$ concentrations $(\mathrm{P}=0.242)$, even though their respective average ranges of $2965-4771 \mathrm{mg} / \mathrm{m}^{3}$ and $3062-7763 \mathrm{mg} / \mathrm{m}^{3}$ suggest so. However, continental schools $\left(\mathrm{N}=42,3683 \mathrm{mg} / \mathrm{m}^{3}\right)$ had significantly higher $\mathrm{CO}_{2}$ levels $(\mathrm{P}<0.001)$ than coastal schools $\left(\mathrm{N}=18 ; 3134 \mathrm{mg} / \mathrm{m}^{3}\right)$, which could be related to warmer weather conditions and therefore better natural ventilation in the coastal area.

Cluster analysis shows that, with the exception of one school in the Osijek area (school No. 1 with the highest mean concentration of $4691 \mathrm{mg} / \mathrm{m}^{3}$ and a completely different $\mathrm{CO}_{2}$ profile), elementary schools did not form any distinct geographical clusters with respect to $\mathrm{CO}_{2}$ levels (Figure 3).

From the moment pupils entered the classroom at 7.55 am, $\mathrm{CO}_{2}$ concentration sharply rose (Figure 4). Slight decreases in $\mathrm{CO}_{2}$ concentration occurred during breaks between classes, probably due to brief ventilation caused by door opening. When classrooms were unoccupied between morning and afternoon shifts, the $\mathrm{CO}_{2}$ concentrations dropped and started to rise again as afternoon classes began.

All schools had a similar $\mathrm{CO}_{2}$ concentration profile but differed in daily morning and afternoon shift maxima. Similar variations have also been reported elsewhere (20). Like in Portuguese schools (17), the classrooms were poorly ventilated due to noise, rain, and cold weather. Furthermore, windows were not opened for ventilation overnight for security reasons. During the night hours, $\mathrm{CO}_{2}$ dropped to concentrations between $1938 \mathrm{mg} / \mathrm{m}^{3}$ and $3876 \mathrm{mg} / \mathrm{m}^{3}$. Even in the early morning hours before classes began on Monday, the initial $\mathrm{CO}_{2}$ concentration in $30 \%$ of the classrooms ranged from 2132 to $4651 \mathrm{mg} / \mathrm{m}^{3}$, probably due to overheating.

Particularly high $\mathrm{CO}_{2}$ levels (going over the upper quantification limit of $9689 \mathrm{mg} / \mathrm{m}^{3}$ ) were found in computer classes. Similar findings reported earlier (26-28) indicate that low air quality in computer classes could be a result of 


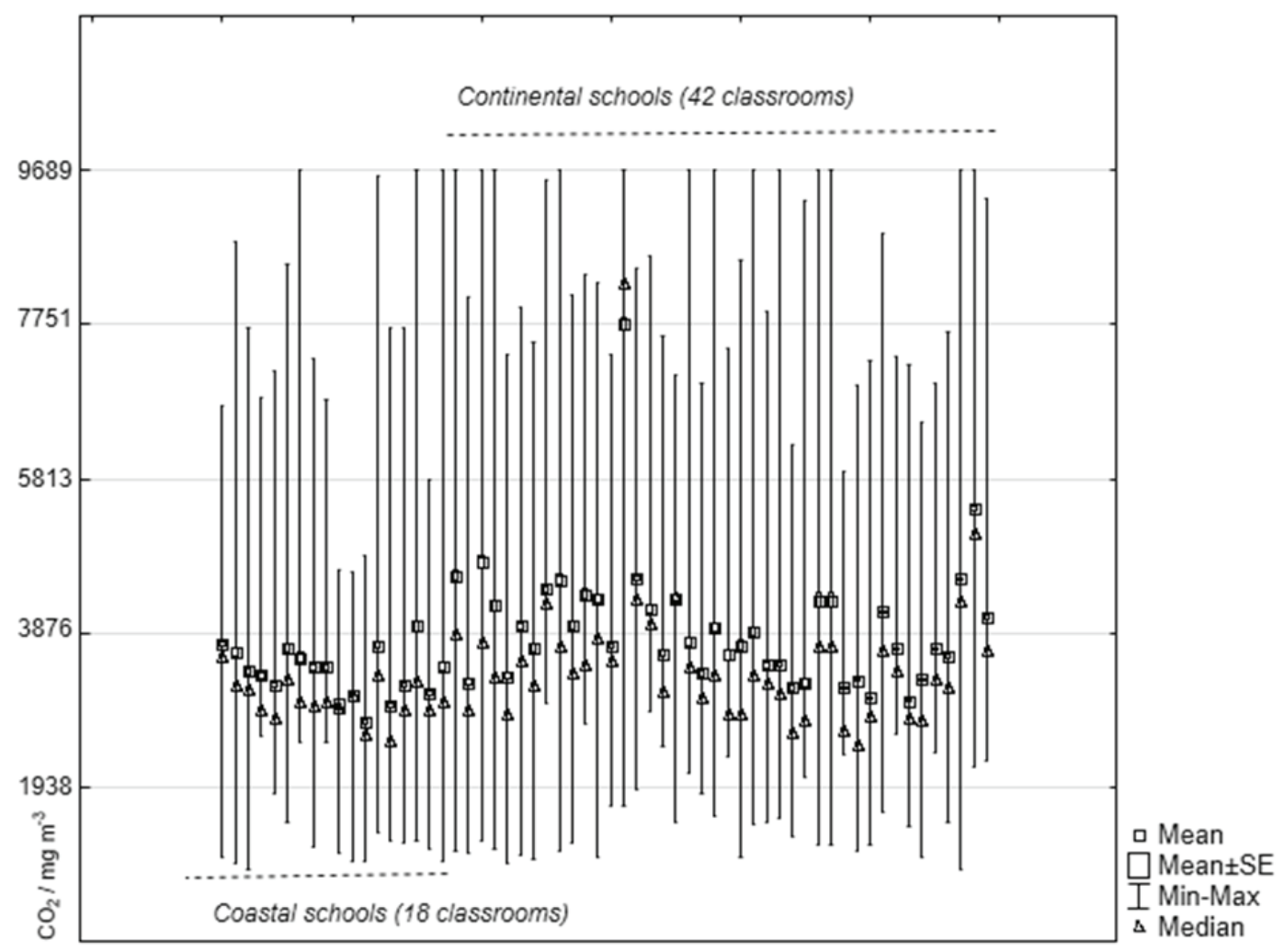

Figure $2 \mathrm{CO}_{2}$ concentrations in classrooms during one school week (Monday to Friday)

Complete Linkage

Squared Euclidean distances

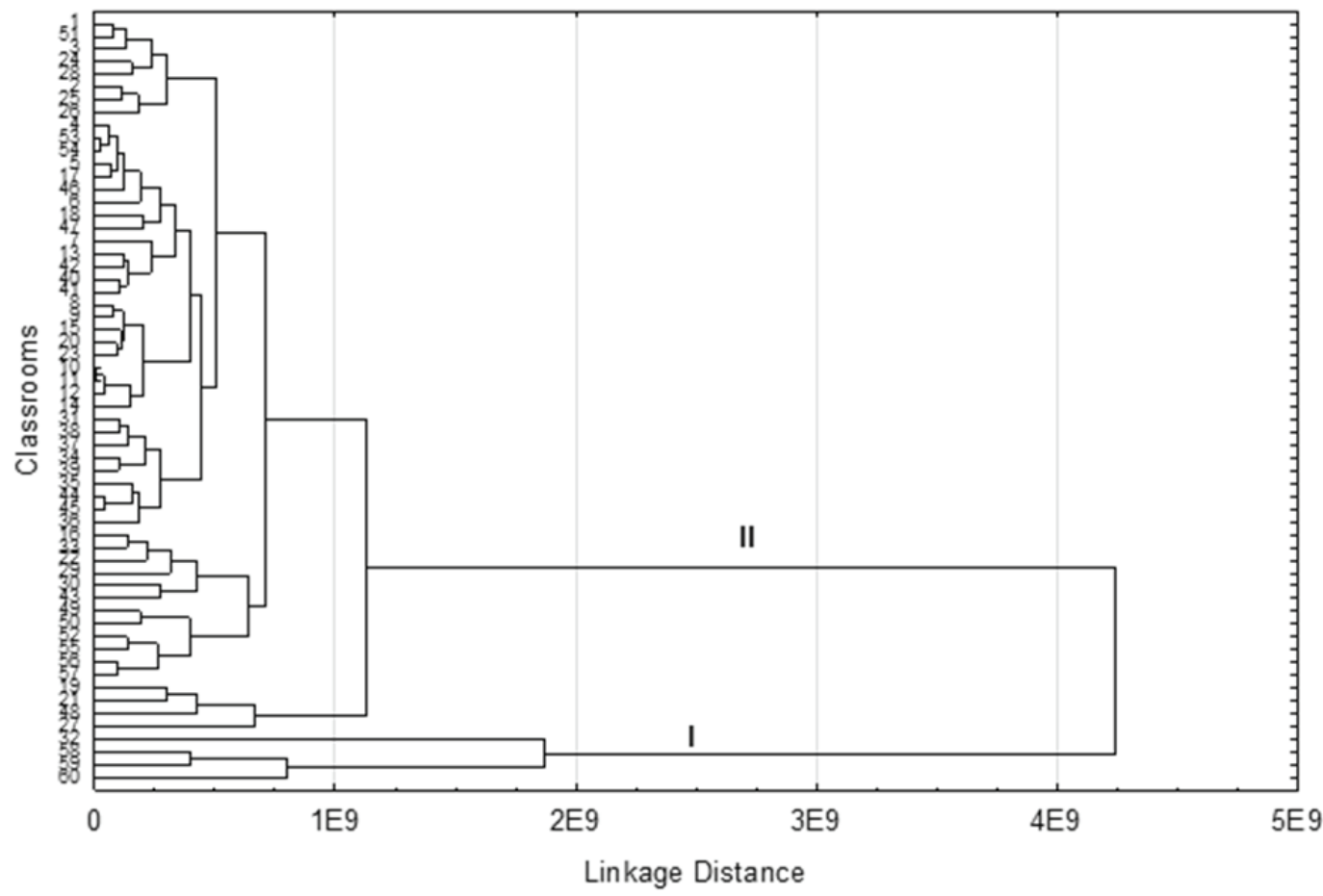

Figure 3 Cluster analysis dendrogram of all 60 classes included in the study. At higher distances two clusters can be observed: a threemember cluster (I) corresponding to classes in one urban school located in the eastern part of Croatia (Osijek) and a complex mixed (rural/urban) cluster (II) which at lower distances split into clusters showing the remaining schools 


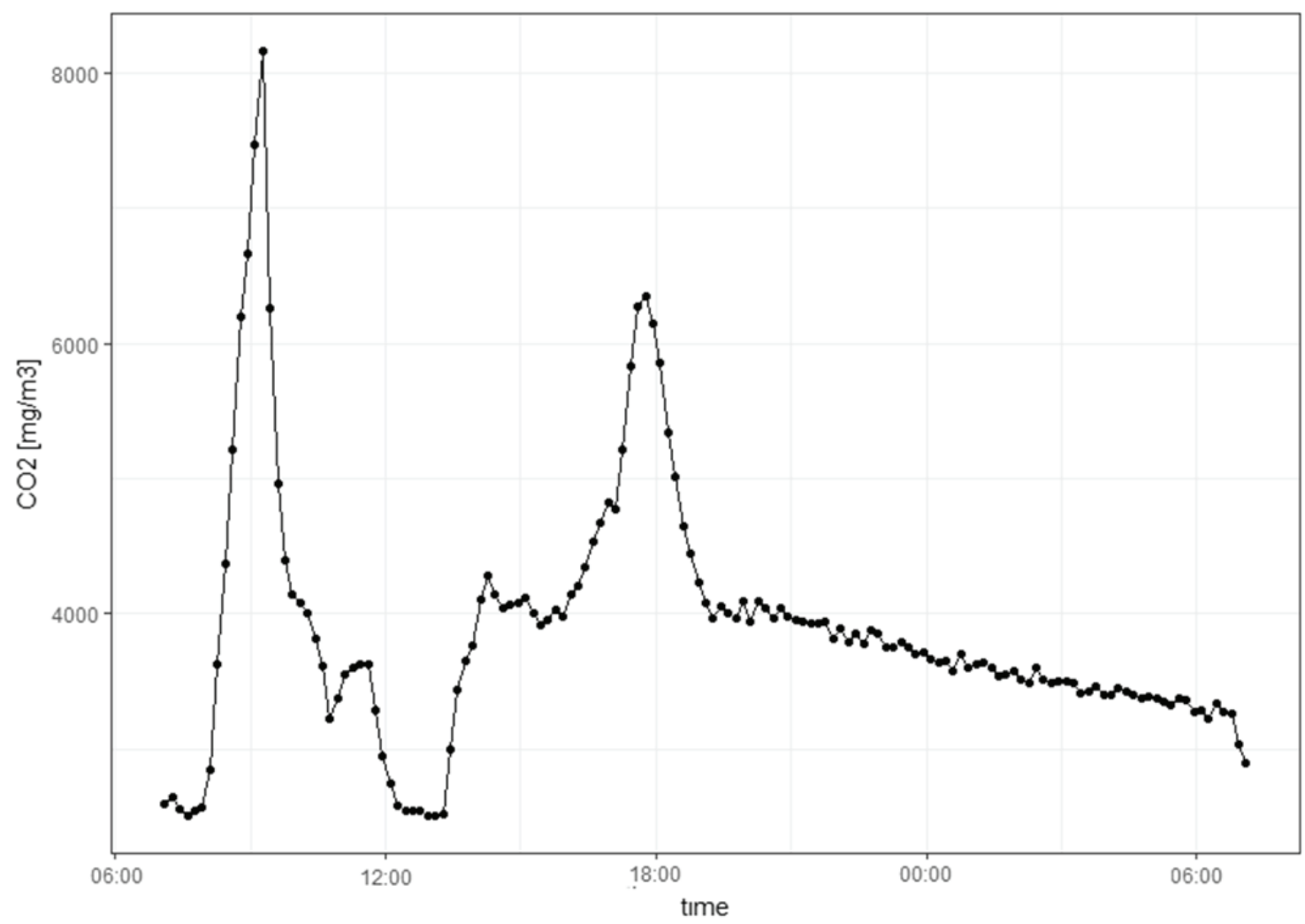

Figure 4 An example of 24-hour fluctuations of $\mathrm{CO}_{2}$ in a classroom

poor air ventilation. During the night, $\mathrm{CO}_{2}$ concentrations in vacant computer classrooms were very high and stable.

In our study, $\mathrm{CO}_{2}$ concentrations in the classrooms were higher than those reported in Serbia (19) and Portugal (17), where mean values ranged from 2093 to $2484 \mathrm{mg} / \mathrm{m}^{3}$, but are consistent with another Serbian study (20) conducted in five rural and urban elementary schools during the heating season, with mean values going up to $3627 \mathrm{mg} / \mathrm{m}^{3}$. Similar to ours were also the results of a study conducted in Albanian schools during the cold season, which often exceeded $1938 \mathrm{mg} / \mathrm{m}^{3}$ at the beginning of the first morning class and ranged between 3225 and $9069 \mathrm{mg} / \mathrm{m}^{3}$ (18).

Three years after our study was conducted, the Sixth Ministerial Conference on Environment and Health convened in Ostrava, Czech Republic, in 2017 to review developments since the 2010 Parma conference (29). The resulting Ostrava Declaration on Environment and Health set improving indoor and outdoor air quality as one of major priorities (30) and has been used as a platform for the implementation of environmental and health goals and targets of the 2030 Agenda for Sustainable Development $(31,32)$.

\section{CONCLUSION}

This observational study measured $\mathrm{CO}_{2}$ concentrations in a real-life setting but did not measure the direct effects of increased $\mathrm{CO}_{2}$ on pupils. With $\mathrm{CO}_{2}$ concentrations consistently above the recommended maximum of
$1938 \mathrm{mg} / \mathrm{m}^{3}$ in all 20 schools, it clearly points to poor classroom ventilation, which remains an issue to be addressed by further multidisciplinary research and solutions that would improve indoor air conditions in schools to become more beneficial for students.

\section{Acknowledgements}

This work was supported by the Ministry of Health of the Republic of Croatia through a special program "Monitoring of the Implementation of the Parma Declaration Indicators". The beneficiary of this support was the Croatian Institute of Public Health.

\section{Conflicts of interests}

None to declare.

\section{REFERENCES}

1. Fiala Z, Vyskocil A, Krajak V, Viau C, Ettlerova E, Bukac J, Fialova D, Emminger S. Environmental exposure of small children to polycyclic aromatic hydrocarbons. Int Arch Occup Environ Health 2001;74:411-20. doi: 10.1007/s004200100239

2. Stranger M, Potgieter-Vermaak S, Van Grieken R. Characterization of indoor air quality in primary schools in Antwerp, Belgium. IndoorAir 2008;18:454-63. doi: 10.1111/j.1600-0668.2008.00545.x

3. Selgrade MK, Plopper CG, Gilmour MI, Conolly RB, Foos BS. Assessing the health effects and risks associated with children's inhalation exposures - asthma and allergy. J Toxicol Environ Health A 2007;71:196-207. doi: 10.1080/15287390701597897 
4. Canha N, Martinho M, Almeida-Silva M, Almeida SM, Pegas P, Alves C, Pio C, Ascensão Trancoso M, Sousa R, Mouro F, Contreiras T, Freitas MdC. Indoor air quality in primary schools. Int J Environ Pollut 2012;50:396-410. doi: 10.1504/ IJEP.2012.051210

5. Seppänen O, Fisk W, Mendell M. Association of ventilation rates and $\mathrm{CO}_{2}$ concentrations with health and other responses in commercial and institutional buildings. Indoor Air 1999;9:226-52. doi: 10.1111/j.1600-0668.1999.00003.x

6. Wargocki P, Sundell J, Bischof W, Brundrett G, Fanger PO, Gyntelberg F, Hanssen SO, Harrison P, Pickering A, Seppänen $\mathrm{O}$, Wouters P. Ventilation and health in non-industrial indoor environments: report from a European Multidisciplinary Scientific Consensus Meeting (EUROVEN). Indoor Air 2002;12:113-28. doi: 10.1034/j.1600-0668.2002.01145.x

7. Sundell J, Levin H. Ventilation Rates and Health: Report of an Interdisciplinary Review of the Scientific Literature. Final report. Atlanta: American Society of Heating, Refrigerating and Airconditioning Engineers; 2007.

8. World Health Organization (WHO). School Environment: Policies and Current Status, 2015 [displayed 21 September 2017]. Available at http://www.euro.who.int/_data/assets/pdf file/0009/276624/School-environment-Policies-current-status-en. pdf

9. Haverinen-Shaughnessy U, Moschandreas D, Shaughnessy R. Association between substandard classroom ventilation rates and students' academic achievement. Indoor Air 2011;21:121-31. doi: 10.1111/j.1600-0668.2010.00686.x

10. Park H, Lee B, Ha E-H, Lee J-T, Kim H, Hong Y-C. Association of air pollution with school absenteeism due to illness. Arch Pediatr Adolesc Med 2002;156:1235-9. doi: 10.1001/ archpedi.156.12.1235

11. Puteh M, Ibrahim MH, Adnan M, Che'Ahmad CN, Noh NM. Thermal comfort in classroom: constraints and issues. Procedia Soc Behav Sci 2012;46:1834-8. doi: 10.1016/j.sbspro.2012.05.388

12. Eicker U. Cooling strategies, summer comfort and energy performance of a rehabilitated passive standard office building. ApplEnerg 2010;87:2031-9. doi: 10.1016/j.apenergy.2009.11.015

13. Satish U, Mendell MJ, Shekhar K, Hotchi T, Sullivan D, Streufert $\mathrm{S}$, Fisk WJ. Is $\mathrm{CO}_{2}$ an indoor pollutant? Direct effects of low-tomoderate $\mathrm{CO}_{2}$ concentrations on human decision-making performance. Environ Health Perspect 2012;120:1671. doi: 10.1289/ehp.1104789

14. Janssen NA, Hoek G, Brunekreef B, Harssema H. Mass concentration and elemental composition of PM10 in classrooms. Occup Environ Med 1999;56:482-7. doi: 10.1136/oem.56.7.482

15. Gładyszewska-Fiedoruk K. Correlations of air humidity and carbon dioxide concentration in the kindergarten. Energ Buildings 2013;62:45-50. doi: 10.1016/j.enbuild.2013.02.052

16. Almeida RM, de Freitas VP. Indoor environmental quality of classrooms in Southern European climate. Energ Buildings 2014;81:127-40. doi: 10.1016/j.enbuild.2014.06.020

17. Ferreira AMC, Cardoso SM. Exploratory study of air quality in elementary schools, Coimbra, Portugal. Rev Saude Publ 2013;47:1059-68. doi: 10.1590/S0034-8910.2013047004810

18. Hänninen O, Canha N, Kulinkina AV, Dume I, Deliu A, Mataj E, Lusati A, Krzyzanowski M, Egorov A. Analysis of $\mathrm{CO}_{2}$ monitoring data demonstrates poor ventilation rates in Albanian schools during the cold season. Air Qual Atmos Health 2017;10:773-82. doi: 10.1007/s11869-017-0469-9

19. Jovanović M, Vučićević B, Turanjanin V, Živković M, Spasojević V. Investigation of indoor and outdoor air quality of the classrooms at a school in Serbia. Energy 2014;77:42-8. doi: 10.1016/j. energy.2014.03.080

20. Turanjanin V, Vučićević B, Jovanović M, Mirkov N, Lazović I. Indoor $\mathrm{CO}_{2}$ measurements in Serbian schools and ventilation rate calculation. Energy 2014;77:290-6. doi: 10.1016/j. energy.2014.10.028

21. World Health Organization (WHO). Parma Declaration on Environment and Health, 2010 [displayed 21 September 2017]. Available at http://www.euro.who.int/_data/assets/pdf file/0011/78608/E93618.pdf

22. Brdarić D, Egorov A, Valek M, Hanninen O, HaverinenShaughnessy U, Wendland C. Pilot exposure assessment survey in schools in Osijek, Croatia using a standardized methodology of World Health Organization. In: $2^{\text {nd }}$ Environmental Health Congress Environmental Health at the Service of Human Health; 24-26 Apr 2013; Zagreb, Croatia. Book of abstracts p. 69.

23. Brdarić D, Barišin A, Capak K, Egorov A, Jelinić Doko J, Naumova E, Kulinkina A, Sellitto M. Problems with moulds/ dampness in schools - Croatian review on Parma declaration commitments. In: Vitale K, editor. Learning Spaces in Transition. Typology for Healthy Learning Environments. Zagreb: University of Zagreb, UNICEF; 2015. p. 36-40.

24. Brdarić D, Barišin A, Capak K, Valek M, Ujević-Bošnjak M, Egorov A. Special program: Monitoring of environmental Health Indicators of Parma Declaration in primary schools in the Republic of Croatia. In: $2^{\text {nd }}$ Environmental Health Congress Environmental Health at the Service of Human Health; 24-26 Apr 2013; Zagreb, Croatia. Book of abstracts. p. 3.

25. Kimo Instruments. Kistock, user manual [displayed 21 September 2017].Available athttps://elma.dk/Admin/Public/DWSDownload. aspx File $=\% 2$ Ffiles $\%$ Ffiles $\% 2$ Fdocuments $\% 2$ Fecom $\% 2$ FManuals\%2F5706445791132_UK Kilog Elma.pdf

26. Telejko M. Indoor air quality in computer labs. Struct Environ 2015;7:194-8.

27. Telejko M. Attempt to improve indoor air quality in computer laboratories. Procedia Engin 2017;172:1154-60. doi: 10.1016/j. proeng.2017.02.134

28. Norbäck D, Nordström K. An experimental study on effects of increased ventilation flow on students' perception of indoor environment in computer classrooms. Indoor Air 2008;18:293300. doi: 10.1111/j.1600-0668.2008.00530.x

29. World Health Organization (WHO). Report of the Sixth Ministerial Conference on Environment and Health, 2017 [displayed 29 November 2019]. Available at http://www.euro. who.int/_data/assets/pdf file/0003/360453/ostrava-report-eng. pdf?ua $=1$

30. World Health Organization (WHO). Declaration of the Sixth Ministerial Conference on Environment and Health, 2017 [displayed 29 November 2019]. Available at http://www.euro. who.int/_data/assets/pdf_file/0007/341944/OstravaDeclaration SIGNED.pdf

31. World Health Organization (WHO). Declaration of the Sixth Ministerial Conference on Environment and Health, Scope and purpose, 2017 [displayed 29 November 2019]. Available at http:// www.euro.who.int/_data/assets/pdf_file/0019/334450/EUROOstrava-2017-02-Scope-and-Purpose-en.pdf?ua=1

32. World Health Organization (WHO). Air Quality and Health, 2018 [displayed 29 November 2019]. Available at http://www.euro. who.int/_data/assets/pdf_file/0004/381919/fs-sdg-air-qualityhealth-eng.pdf 


\section{Koncentracije ugljikova dioksida u učionicama hrvatskih osnovnih škola tijekom sezone grijanja}

Izloženost zagušljivom zraku u zatvorenom prostoru s visokim razinama ugljikova dioksida (CO, povezano je s izostancima s nastave i lošijim uspjehom u školi. Regionalni ured Svjetske zdravstvene organizacije (WHO) za Europu razvio je provedbu istraživanja o kvaliteti zraka u zatvorenim prostorima u školama, uključujući praćenje $\mathrm{CO}_{2}$ kako bi se procijenila ventilacija i izloženost zagušljivom zraku. Ovo je bilo prvo istraživanje o kvaliteti zraka u zatvorenim prostorima $u$ hrvatskim osnovnim školama uz praćenje $\mathrm{CO}$ kao pokazatelja kvalitete zraka i ventilacije. Istraživanje je provedeno u 60 učionica u 20 urbanih i ruralnih osnovnih škola diljem zemlje tijekom sezone grijanja. Razine $\mathrm{CO}_{2}$ mjerene su s intervalom od jedne minute tijekom jednoga školskoga tjedna u svakoj učionici. Međunarodne smjernice od $1938 \mathrm{mg} / \mathrm{m}^{3}$ premašene su u svih 60 učionica. Srednje koncentracije CO tijekom nastave bile su u rasponu od 2771 do $7763 \mathrm{mg} / \mathrm{m}^{3}$. Najveća srednja koncentracija u urbanim školama iznosila je oko $7763 \mathrm{mg} / \mathrm{m}^{3}$, a najveća srednja koncentracija CO u ruralnim školama oko $4771 \mathrm{mg} / \mathrm{m}^{3}$. Prosječne razine $\mathrm{CO}_{2}$ bile su veće u školama u kontinentalnim područjima $\left(3683\right.$ mg/m $\left.\mathrm{m}^{3}\right) \mathrm{u}$ usporedbi s obalnim područjima $\left(3134 \mathrm{mg} / \mathrm{m}^{3}\right)$. Rezultati upozoravaju na slabu ventilaciju u učionicama tijekom hladne sezone kao široko rasprostranjen problem u Hrvatskoj.

KLJUČNE RIJEČI: Hrvatska; kvaliteta zraka u zatvorenom prostoru; učionice; ventilacija 